\title{
Solid Biomass Energy Potential as a Development Opportunity for Rural Communities
}

\author{
Mariusz Jerzy Stolarski *(D), Paweł Dudziec, Michał Krzyżaniak (D) and Ewelina Olba-Zięty (D) \\ Department of Genetics, Plant Breeding and Bioresource Engineering, Faculty of Agriculture and Forestry, \\ Centre for Bioeconomy and Renewable Energies, University of Warmia and Mazury in Olsztyn, 10-724 Olsztyn, \\ Poland; pawel.dudziec@student.uwm.edu.pl (P.D.); michal.krzyzaniak@uwm.edu.pl (M.K.); \\ e.olba-ziety@uwm.edu.pl (E.O.-Z.) \\ * Correspondence: mariusz.stolarski@uwm.edu.pl; Tel.: +48-89-5234838
}

Citation: Stolarski, M.J.; Dudziec, P.; Krzyżaniak, M.; Olba-Zięty, E. Solid Biomass Energy Potential as a Development Opportunity for Rural Communities. Energies 2021, 14, 3398. https://doi.org/10.3390/en14123398

Academic Editor: Robert H. Beach

Received: 5 May 2021

Accepted: 3 June 2021

Published: 9 June 2021

Publisher's Note: MDPI stays neutral with regard to jurisdictional claims in published maps and institutional affiliations.

Copyright: (c) 2021 by the authors. Licensee MDPI, Basel, Switzerland. This article is an open access article distributed under the terms and conditions of the Creative Commons Attribution (CC BY) license (https:// creativecommons.org/licenses/by/ $4.0 /)$.

\begin{abstract}
Conventional energy sources often do not fully satisfy the needs of a modern economy, especially given the climate changes associated with them. These issues should be addressed by diversification of energy generation, including the development of renewable energy sources (RES). Solid biomass will play a major part in the process in Poland. The function of rural areas, along with a well-developed agricultural and forest economy sector, will be a key aspect in this as these areas are suitable for solid biomass acquisition in various ways. This study aimed to determine the solid biomass energy potential in the commune of Goworowo to illustrate the potential in the smallest administrative units of Poland. This research determined the environmental and natural conditions in the commune, which helped to identify the crucial usable solid biomass resources. The total energy potential of solid biomass resources in the commune of Goworowo amounted to 97,672 GJ $\mathrm{y}^{-1}$. The highest potential was accumulated in straw surplus $\left(37,288 \mathrm{GJ}^{-1}\right)$ and the lowest was in wood from roadside maintenance $\left(113 \mathrm{GJ}^{-1}\right)$. This study showed that rural areas could soon play a significant role in obtaining solid biomass, and individual communes could become spaces for the diversification of energy feedstock.
\end{abstract}

Keywords: solid biomass; bioenergy potential; rural communities; forest residues; agricultural residues; straw; energy crops

\section{Introduction}

A region's economic development depends on access to energy and conventional resources such as coal, natural gas and oil are no longer sufficient to satisfy the increasing demand from the economy. Moreover, non-renewable energy sources contribute to climate changes, making it necessary to seek alternative options, including renewable solutions (RES) [1-3]. Energy generation in Poland is based on hard coal and brown coal, which boosts the greenhouse effect and, since fossil fuel resources are highly likely to be exhausted, measures should be taken to promote RES, whose supply is unlimited. Since coal accounted for 77\% of all energy carriers used in Poland in 2019, it is claimed that the proportion of RES in the energy mix in Poland is insufficient $[1,4]$. Pressure from both society and the international community necessitates changes in the energy source structure, and the removal of coal from power generation in Poland is still too slow [3,4]. However, pressure is growing, as the solutions proposed by the European Commission at the UN COP25 climate summit in Madrid assume that the European economy will have achieved climatic neutrality by 2050 (The European Green Deal). The realization of this idea would require the implementation of multiple measures covering all aspects of EU citizens' lives, including bioeconomy-a topic which is not covered by any Polish strategic document $[5,6]$.

Energy from RES includes energy from biomass, solar energy, energy from water, wind, geothermal sources and energy from the environment obtained using heat pumps. 
The proportion of energy from RES in the structure of energy generation in Poland has been increasing in recent years, but it is still small. RES accounted for $16.0 \%$ of the total primary energy in 2019; more than in 2014-2018 (by 3.9, 2.9, 2.4, 1.7 and 1.5 percentage points, respectively). At the same time, the average proportion of energy from renewable sources in the total primary energy in the EU-28 increased much faster-from $26.1 \%$ in 2014 to $32.8 \%$ in 2019 [7-10]. This situation necessitates a greater use of renewable energy to increase the proportion of RES in energy generation.

Solid biomass is the dominant RES in Poland and it accounted for $65.6 \%$ of the total in 2019 , with $55 \%$ of the amount being consumed by end-users without being converted to another energy carrier. Solid biomass is the leader in heat generation from RES in Poland (90.1\% in 2019) and it also accounted for $25.1 \%$ of electricity generation in 2018 , with only wind energy having a larger share [11]. The proportion of biomass can increase since individual solid fuel-fired boilers do not increase total operating costs compared to fossil fuel-fired boilers. Nearly $60 \%$ of the EU-28 population live in houses that require heating boilers, many of which have to be replaced [12].

Diversified renewable energy is now the most promising sustainable energy system instead of non-renewable and centralized systems. Local generation and distribution of energy increases the system reliability and reduces the distribution related loss, which is the case with the centralization of energy sources [13]. Therefore, a single region should be regarded as a not-fully-used energy system considering the RES resources present in it. Such activities align with the concept of sustainable development and circular economy [1] because seeking local and renewable energy sources guarantees their development, which is important given the crisis resulting from the exhaustion of conventional energy sources [4]. Therefore, sustainable development can be achieved through the development of society, which is guided by a comprehensive approach to products and/or services concerning materials and energy and ensures raw material effectiveness and economic growth throughout the product life cycle [14].

The territory of Poland is divided into regions, with the administrative division being the most common manifestation of regionalization. Poland is divided into 16 voivodships, 314 districts and 2477 communes as the smallest administrative units. There are 302 urban communes, 642 urban-rural communes and 1533 rural communes [15]. Considerable parts of rural areas contain potential sources of solid biomass which could play a special role in the local energy system, especially since the average commune size is 12,500 ha [16]. It should be noted that rural communes have good conditions for the diverse use of green energy. This applies particularly to agriculture, which can facilitate the transition from a fossil fuel-based economy to an economy based on renewable energy $[4,6]$. Significant benefits from solid biomass use as energy feedstock include regional energy independence, the prevention of low emissions, the creation of new jobs, the use of marginal land, agricultural and forest residue management, local communities becoming motivated to act for the benefit of the environment and, primarily, the opportunity to obtain clean energy [1] Agriculture in EU countries is consuming increasing amounts of energy, which has resulted in the diversification of its resources and the growing importance of RES. Introducing green energy presents an opportunity for agriculture modernization without intensifying its adverse impact on the environment [17].

To date, the energy potential of agricultural residues in 294 countries of the world has been determined [18], as well as the solid biomass energy potential in Switzerland [19] and Turkey [20]. Stolarski et al. [21] determined the bioenergy potential of the countries bordering the Baltic Sea, including Poland. Smaller regions, i.e., districts, were dealt with by Kowalczyk-Juśko et al. [22]. However, there were no detailed papers in the literature that provided a comprehensive methodology of the conducted studies or analyses of the biomass energy potential in individual communes considering their specific local conditions. Although such studies are of significance to the diversification of local energy sources which ultimately affects the country's energy balance, the number of in-depth scientific papers on the topic is low. Therefore, taking up this subject was justified since 
this forecast could affect the investment decisions concerning energy generation and consequently increase the RES proportion in the local generation structure. This study aimed to determine the solid biomass resources and the energy potential in the Commune of Goworowo. This analysis should be used as the basis for changes in the local strategies of regional development, raising social awareness of the potential and local use of RES in rural areas.

\section{Materials and Methods}

The research was conducted in the commune of Goworowo (the commune is the basic unit in the administrative division of Poland). Goworowo is a typical rural commune in the north Mazovian Lowland, whose conditions are representative of those of central-eastern Poland. The methodological work was started by determining the environmental and natural conditions in the commune with respect to the solid biomass acquisition potential. The materials that were originally accumulated were used to identify the most significant and usable sources within the administrative unit under study. Data were mainly gathered using the official, up-to-date administrative databases. It is noteworthy that there are often no data solely concerning the administrative area of a commune in Poland as there may be several managing bodies whose authority extends over a commune, as is the case with forest lands.

The next stage involved the determination of the solid biomass amount from various sources based on the processed data and the methodology presented further in the paper. As a consequence, the total solid biomass energy potential could be referred to hard coal-the most common energy source in Poland, including rural areas [9]. The specific local conditions in the commune were considered when the solid biomass resources in it were determined.

\subsection{Characteristics of the Commune}

\subsubsection{Administrative Affiliation and General Information}

The commune of Goworowo covered an area of 21,909.44 ha in 2020 [23]. Administratively, it is part of the Mazowieckie Voivodship and is situated in the north-east of the voivodship, in the southern part of the Ostrołecki District, $52^{\circ} 54^{\prime} \mathrm{N} 21^{\circ} 33^{\prime} \mathrm{E}$ [24]. The relative position of the commune in the administrative units is shown in Figure 1.

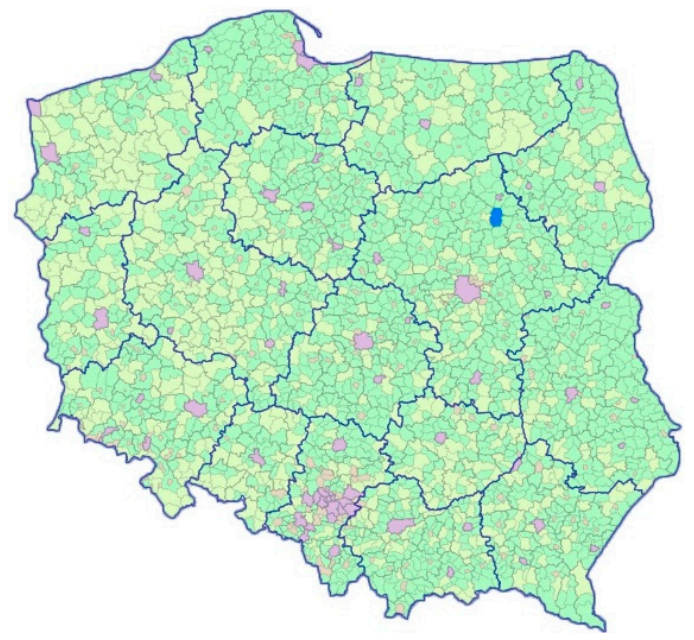

(a)

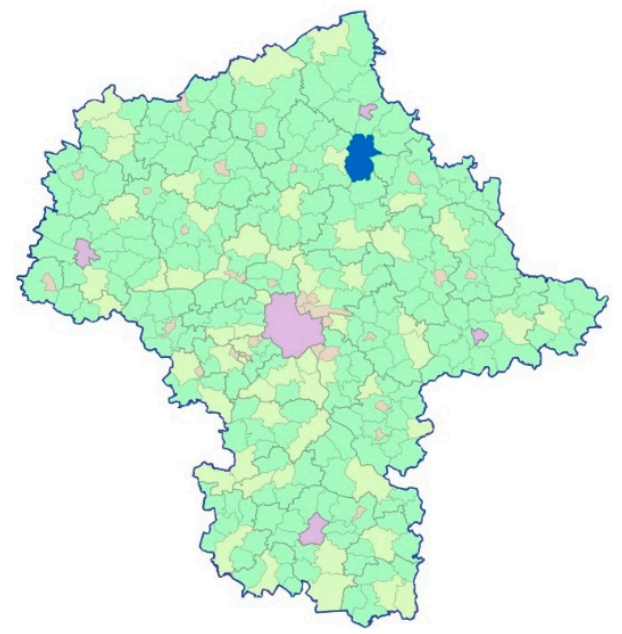

(b)

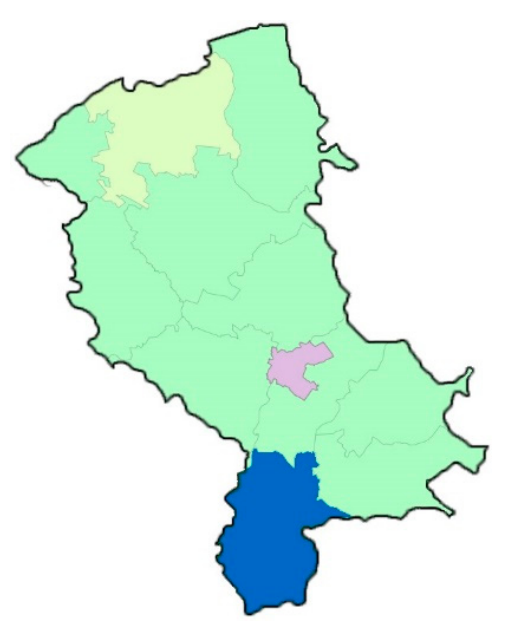

(c)

Figure 1. Position of the commune of Goworowo (blue): (a) in Poland; (b) in the Mazowieckie Voivodship; (c) in the Ostrołęcki District.

It had a population of 8455 people at the end of December 2019, which accounted for $9.5 \%$ of the population of the Ostrołecki District. The population density in the commune was 39 people per $\mathrm{km}^{-2}$. The unit under analysis was a commune with a medium- 
sized population and area when compared to the other communes in the Ostrołecki District $[23,25]$. When compared to all 2478 communes in Poland, Goworowo had a nearly twice smaller population (an average of 15,500 people) and its area was nearly twice larger than the average (12,500 ha) [16,23].

It is an agricultural commune, with dominating individual farming oriented towards dairy cattle breeding. Swine are also bred. In crop production, grain crops, corn for silage and root crops dominate. Non-agricultural business activities include services-mainly food industry related, forestry related and in the repair and construction and transport area. Industry includes only production and service facilities. Currently, the agriculture, construction and processing industries enjoy the greatest development opportunity in the commune, along with rural tourism, including agrotourism and organic farms. Therefore, using RES would be in line with this development trend. There were no industrial facilities within the commune that posed an increased or high risk of industrial failure $[23,26]$.

\subsubsection{Land Use}

The commune land was mainly covered by forest or used for agriculture, with farmland accounting for $61.87 \%$ of the total area and forest for $32.36 \%$ (Table 1 ). The other lands accounted for $5.77 \%$ of the commune area [23].

Table 1. Land use structure in the commune of Goworowo.

\begin{tabular}{cc}
\hline Item & Proportion of the Area (\%) \\
\hline Farmland & 61.87 \\
Farmland with trees and bushes & 0.80 \\
Forest land & 32.36 \\
Wasteland & 0.97 \\
Built-up and urbanized area & 2.86 \\
Land under waters & 1.05 \\
Other land & 0.09 \\
\hline
\end{tabular}

Residential buildings occupied the greatest part of the built-up area (41\%) followed by farmstead buildings (39\%). Approximately $8 \%$ of the area was occupied by recreational buildings and $2 \%$ by service and industrial facilities $[23,26]$.

The soil classification system in Poland includes soils from class I (best) to class VI (poorest). Arable land class V and VI in the commune of Goworowo (excluding orchards) altogether accounted for $56.1 \%$. Permanent grassland was dominated by poor and very poor quality soils $(62.8 \%)$, with larger complexes of such land occurring in the north and in the south of the commune, where disadvantageous moisture content in the soil (requiring soil melioration) dominated [27]. Class IV soils dominated in orchards.

Better soils were formed on loams and glacial dust and were present in vast and compact areas in the commune center. These included medium and good soils, mainly acidic brown soils with occasional podsolic or pseudo-podsolic soils. However, poor and very poor quality soils, brown acidic soils and podsolic soils formed on glacial sand dominated in the south and the north of the commune [28]. The commune was among the areas of the Mazowieckie Voivodship with medium-advantageous conditions for agriculture development.

\subsubsection{Structure of Agricultural Land}

Arable land (9571.03 ha) dominated the farmland. Grassland-pastures (1784.00 ha) and meadows (1543.16 ha)—occupied a much smaller area. Orchards covered the smallest area (21.96 ha) [23].

The major crop area was determined based on the average crop production area structure in the Mazowieckie Voivodship [29]. Therefore, the area where crops were produced accounted for $77 \%$ of the entire arable land. The remaining $23 \%$ was occupied 
by agriculture or horticulture supporting facilities and structures, fallow land and areas occupied by ornamental tree plantations and ornamental tree or bush nurseries [29-31].

The cultivated area of species constituting the most important, primary source of straw was 5556.15 ha (Table 2).

Table 2. Pattern of crops-exclusively main sources of straw.

\begin{tabular}{cc}
\hline Crop & Area (ha) \\
\hline Triticale & 1180.31 \\
Wheat & 1039.30 \\
Cereal mixtures & 968.70 \\
Rye & 913.76 \\
Oat & 526.98 \\
Grain maize & 367.29 \\
Barley & 297.95 \\
Rape and turnip-like rape & 261.86 \\
\hline
\end{tabular}

\subsection{Determination of Biomass Resources and Their Energy Potential}

\subsubsection{Straw}

The amount of straw depends on the production area of crops which produce straw as a by-product, grain yield, crop species, fertilization, agricultural practices and climate and soil conditions [21]. The grain-straw coefficient index (Table 3) enables the theoretical determination of the straw amount per 1 ha of crop cultivation area [32-34].

Table 3. Yield and grain/straw coefficient for crops.

\begin{tabular}{ccc}
\hline Crop & Mean Grain Yield (Mg ha -1) $^{-}$ & Grain/Straw Coefficient \\
\hline Wheat (mean for winter and spring yield) & 4.47 & 0.93 \\
Triticale (mean for winter and spring yield) & 3.69 & 1.16 \\
Rye (as winter crop) & 3.24 & 1.45 \\
Barley (mean for winter and spring yield) & 4.22 & 0.78 \\
Cereal mixtures (mean for winter and spring yield) & 3.42 & 1.10 \\
Oat & 3.07 & 1.05 \\
Rape and turnip-like rape & 3.15 & 1.00 \\
Grain maize & 11.95 & 1.40 \\
\hline
\end{tabular}

However, not all straw can be collected during harvest due to the field conditions or the height at which the harvester cuts down the crop. Moreover, some straw is lost while being collected, baled and transported. Since the analyses conducted in straw-fired boilers also showed that the available straw amount calculations based on the grain/straw coefficient produce excessive results, the technical and practical potential for straw acquisition in cereal and oily crop production was calculated to be $60 \%$ (coefficient 0.6 ). This means that the average yield of straw collected from the field in bales corresponded to 0.6 of the grain yield [21]. Therefore, the total straw yield was determined based on the yield of cereals, rape and turnip-like rape from the Equation (1):

$$
\mathrm{Y}_{\mathrm{S}}=0.6 \cdot \mathrm{Y}_{\mathrm{G}}
$$

where:

$\mathrm{Y}_{\mathrm{S}}$ - straw yield $\left(\mathrm{Mg} \mathrm{y}^{-1}\right)$,

$\mathrm{Y}_{\mathrm{G}}$ - grain yield $\left(\mathrm{Mg} \mathrm{y}^{-1}\right)$.

Moreover, large amounts of straw are used in animal production as fodder and bedding. Straw should also be ploughed under and returned to the soil to maintain the organic matter balance. The straw surplus in Poland, usable as an energy feedstock, accounts for 33\% of the total straw produced [35]. However, the surplus was adjusted in the current study due to the local conditions. The straw consumption coefficient was 
increased because cattle and swine breeding in the bedding system dominated in the commune of Goworowo. Therefore, it was assumed for these analyses that the demand for straw as bedding, fodder and for ploughing-under in the commune was: $26 \% ; 16 \%$ and $39 \%$ of the total straw yield, respectively, which gave a total of $81 \%$. Therefore, the straw surplus unused in agriculture in the commune of Goworowo was only $19 \%$. This figure was considered in calculations of the straw surplus potential, which can be used as energy feedstock (2), assuming that the mean lower heating value (LHV) was $14 \mathrm{GJ} \mathrm{Mg}^{-1}$ [36] (3):

$$
\mathrm{Y}_{\mathrm{Se}}=0.19 \cdot \mathrm{Y}_{\mathrm{S}}
$$

where:

$\mathrm{Y}_{\mathrm{Se}}$-straw yield for energy purposes $\left(\mathrm{Mg}^{-1}\right)$,

$\mathrm{Y}_{\mathrm{S}}$ - straw yield $\left(\mathrm{Mg} \mathrm{y}^{-1}\right)$.

Subsequently, the straw energy value was determined:

$$
\mathrm{Q}_{\mathrm{S}}=\mathrm{Y}_{\mathrm{Se}} \cdot \mathrm{LHV}
$$

where:

$\mathrm{Q}_{\mathrm{S}}$ - energy potential of straw $\left(\mathrm{GJ} \mathrm{y}^{-1}\right)$,

$\mathrm{Y}_{\mathrm{Se}}$-straw yield for energy purposes $\left(\mathrm{Mg}^{-1}\right)$,

LHV-lower heating value ( $\mathrm{GJ} \mathrm{Mg}^{-1}$ ).

\subsubsection{Orchard Wood Residue}

Wood residue in orchards is produced mainly by annual pruning of trees [37], done to shape the tree crown and obtain the optimum fruit yield. Trees are usually pruned in winter and spring, depending on the local climate and the tree species [38]. The amount of wood collected after pruning ranges from 1.9 to $5 \mathrm{Mg} \mathrm{ha}^{-1}$ in six-year-old orchards. The apple tree, which dominates in Polish orchards, produces $3.5 \mathrm{Mg}$ of wood biomass per 1 ha from annual pruning. Part of the biomass is mulched and scattered as litter in orchards (in situ mulching). The Mazowieckie Voivodship has the greatest energy potential accumulated in wood residue from pruning apple orchards [38,39].

The majority of orchards in the commune of Goworowo were occupied by fruit tree nurseries in which pruning or soil mulching was not done. They were assumed to account for $60 \%$ of the total area. The remaining part was occupied by apple tree orchards, usually not large-scale orchards. They were not mulched, and the wood obtained in them was used as fuel or for recreational purposes. Therefore, since orchards were often situated on medium quality soils, it was assumed that $3.0 \mathrm{Mg}$ of fresh wood biomass was produced by pruning 1 ha of an orchard.

Moreover, many small orchards (up to 2 ha) could not be cultivated properly or not pruned at all. Consequently, they were excluded from the potential calculations and assumed to account for $10 \%$ of the total. Trees in the commune were pruned manually, so no such limitations were observed as with machine pruning when losses in wood yield are caused by machine use or uneven ground [38]. It was calculated in this study that the potential loss associated with collecting the wood and its transport amounted to $5 \%$. The weight of wood biomass from tree pruning was calculated from the Equation (4):

$$
\mathrm{M}_{\mathrm{O}}=0.4 \cdot \mathrm{A}_{\mathrm{O}} \cdot \mathrm{M} \cdot 0.86
$$

where:

$\mathrm{M}_{\mathrm{O}}-$ mass of wood from the pruning of orchards $\left(\mathrm{Mg} \mathrm{y}^{-1}\right)$,

0.4 -orchards, excluding fruit nurseries,

$\mathrm{A}_{\mathrm{O}}$-orchards area,

$\mathrm{M}-$ mass of wood from pruning $\left(\mathrm{Mg}^{-1} \mathrm{ha}^{-1} \mathrm{y}^{-1}\right)$, 
0.86 - factor taking into account orchards not cultivated properly or excluded from regular pruning (0.90) and taking into account losses associated with harvest and transport (0.95).

Orchard biomass does not differ significantly from forest biomass in terms of its energy properties, which makes it usable as the substitute for the latter [39]. Fresh wood LHV is assumed to be $8.0 \mathrm{GJ} \mathrm{Mg}^{-1}$ [40] (5):

$$
\mathrm{Q}_{\mathrm{O}}=\mathrm{M}_{\mathrm{O}} \cdot \mathrm{LHV}
$$

where:

Qo-energy potential of wood from orchards $\left(\mathrm{GJ}^{-1}\right)$,

$\mathrm{M}_{\mathrm{O}}$ - mass of wood from the pruning of orchards $\left(\mathrm{Mg} \mathrm{y}^{-1}\right)$,

$\mathrm{LHV}$-lower heating value $\left(\mathrm{GJ} \mathrm{Mg}^{-1}\right)$.

\subsubsection{Energy Feedstock from Forests}

Forest land owned by the state in Poland is managed by the State Forests, divided into forest districts-basic forest economic units. The commune of Goworowo is located within three such units: Ostrołęka, Wyszków and Pułtusk with the part managed by each of them occupying $82.37 \%, 1.38 \%$ and $16.25 \%$ of its area, respectively. The annual increment of wood resources in Poland in 2019 amounted to $9.42 \mathrm{~m}^{3} \mathrm{ha}^{-1}$ year $^{-1}$ [41]. It was lower in the commune of Goworowo (as a weighted average from these forest districts) $-5.9 \mathrm{~m}^{3} \mathrm{ha}^{-1}$ year $^{-1}$ [42-44].

Logging residue is one of the most commonly used energy feedstock from forests. Wood obtained from forests in Poland, including logging residue, is classified into quality groups, with smallwood (M2) being one of them. M2 wood accounts for $8 \%$ to $15 \%$ of the whole above-ground wood biomass obtained from a logging area unit (in different administrative units) [45]. Apart from M2, middle-sized wood and logging residue, such as treetops and branches, can be used as fuel. Altogether, this energy feedstock accounts for $17 \%$ of the total wood yield in Poland [46]. It has been stressed that the proportion could be much higher if this category also included M1—wood of a different quality class, now used in industry $[1,47]$.

The total forest biomass potential was determined under the assumption that $74.8 \%$ of the annual wood increment is obtained every year, as it is in Poland [48], with the energy feedstock accounting for $15 \%$ of the total wood yield. The wood loss during logging and transport to the final destination was not taken into account in the yield. Forest land in Poland also includes non-afforested land and land associated with forest management. This fact was considered in the calculations, with the average proportion of the afforested land in forest land calculated to be 0.97 [31,42-44].

The energy potential of logging residues was calculated using the following Equation (6):

$$
\mathrm{V}_{\mathrm{F}}=\mathrm{A}_{\mathrm{F}} \cdot \mathrm{I} \cdot \mathrm{H} \cdot \mathrm{E} \cdot \mathrm{F}
$$

where:

$\mathrm{V}_{\mathrm{F}}$-volume of energy resources from forests $\left(\mathrm{m}^{3} \mathrm{y}^{-1}\right)$,

$\mathrm{A}_{\mathrm{F}}$-forest area (ha),

$\mathrm{I}-$ wood resources increase $\left(\mathrm{m}^{3} \mathrm{ha}^{-1} \mathrm{y}^{-1}\right)$,

$\mathrm{H}$-timber harvest in relation to timber increment (0.748),

E-share of energy resources (0.15),

F-share of afforested land in the forest land area (0.97).

Fresh wood LHV was assumed to be $7.5 \mathrm{GJ} \mathrm{m}^{-3}$ [49] (7):

$$
\mathrm{Q}_{\mathrm{F}}=\mathrm{V}_{\mathrm{F}} \cdot \mathrm{LHV}
$$

where:

$\mathrm{Q}_{\mathrm{F}}$ - energy potential of energy resources from forests $\left(\mathrm{GJ} \mathrm{y}^{-1}\right)$, 
$\mathrm{V}_{\mathrm{F}}$-volume of energy resources from forests $\left(\mathrm{m}^{3} \mathrm{y}^{-1}\right)$,

LHV-lower heating value $\left(\mathrm{GJ} \mathrm{m}^{-3}\right)$.

\subsubsection{Solid Biomass from Roadside Maintenance}

Roadsides are in intensive use and are heavily polluted by transport. They are easily accessible and have to be maintained regularly, for example, to keep the traffic safe. All this makes them a promising source of biomass [50]. The road infrastructure in the commune of Goworowo comprised [26]:

- $\quad$ supralocal roads: $13.5 \mathrm{~km}$ of the trunk road and $101.3 \mathrm{~km}$ of district roads;

- local roads: $123.7 \mathrm{~km}$ of communal roads.

The roadside trees and bushes in the commune were not pruned regularly, although there is 0.4 ha of roadside maintenance area per $1 \mathrm{~km}$ of road, which shows their energy potential [51]. The roadside maintenance area was assumed as 0.2 ha km${ }^{-1}$ for local roads. Approximately $4 \mathrm{Mg} \mathrm{ha}^{-1}$ of fresh woody biomass can be obtained from roadsides annually, but only $25 \%$ of this amount can be acquired in Poland [51], which is why $1 \mathrm{Mg}^{-1}$ year $^{-1}$ was taken for the calculations. Under the Polish Nature Conservation Act [52], only intervention pruning, such as removing dead boughs to improve safety, is allowed, but regular maintenance pruning is not.

It was assumed in the current research that $20 \%$ of the roadside with the maintenance area as given above was overgrown with trees and/or bushes and the yield resulted from all work done, including collection and transport. The following Equation was applied (8):

$$
\mathrm{M}_{\mathrm{R}}=0.2\left(\mathrm{~L}_{\mathrm{SL}} \cdot \mathrm{A}_{\mathrm{SL}}+\mathrm{L}_{\mathrm{L}} \cdot \mathrm{A}_{\mathrm{L}}\right) \cdot \mathrm{H}_{\mathrm{R}}
$$

where:

$\mathrm{M}_{\mathrm{R}}$-mass of wood from roadsides $\left(\mathrm{Mg}^{-1}\right)$,

0.2 -factor taking into account roadsides covered with shrubs and/or trees,

$\mathrm{L}_{\mathrm{SL}}, \mathrm{L}_{\mathrm{L}}$-length of supralocal and local roads $(\mathrm{km})$,

$\mathrm{A}_{\mathrm{SL}}, \mathrm{A}_{\mathrm{L}}$-area of supralocal and local roadsides $\left(\right.$ ha $\mathrm{km}^{-1}$ ),

$\mathrm{H}_{\mathrm{R}}$-timber harvest from roadsides $\left(\mathrm{Mg} \mathrm{ha}^{-1} \mathrm{y}^{-1}\right)$.

Fresh wood LHV is assumed to be $8.0 \mathrm{GJ} \mathrm{Mg}^{-1}$ [40] (9):

$$
\mathrm{Q}_{\mathrm{R}}=\mathrm{M}_{\mathrm{R}} \cdot \mathrm{LHV}
$$

where:

$\mathrm{Q}_{\mathrm{R}}$-energy potential of wood from roadsides $\left(\mathrm{GJ} \mathrm{y}^{-1}\right)$,

$\mathrm{M}_{\mathrm{R}}$ - mass of wood from roadsides $\left(\mathrm{Mg}^{-1}\right)$,

LHV-lower heating value $\left(\mathrm{GJ} \mathrm{Mg}^{-1}\right)$.

\subsubsection{Biomass from Perennial Energy Crops}

Perennial energy crops should be grown mainly on soils of poorer quality, unusable for growing edible crops. Marginal soils, including sandy soils and/or those highly susceptible to erosion, are recommended for growing perennial grasses and short-rotation woody crops. However, poor quality soils are not often used for growing energy crops, although they should be used primarily for this purpose [53]. Growing energy crops can reduce water and wind erosion and enable carbon sequestration in soil [54]. It is therefore prudent to use land of lower agricultural productivity for energy crop plantations. Popular woody energy crops include basket willow (Salix viminalis L.) and grasses such as giant miscanthus (Miscanthus $\times$ giganteus J.M. Greef and M. Deuter) [55-57]. Miscanthus is a C4 plant which can be grown successfully in various climate conditions. It is cultivated on marginal soils and does not need irrigation or intensive fertilization. Owing to its deep root system, it uses water effectively and prevents soil erosion. These properties make its cultivation recommended in areas threatened with erosion and with poor water availability [58].

Aerenchyma cells present in stems and roots also improve the gas exchange effectiveness, enabling it to grow on wetlands [54]. Miscanthus $\times$ giganteus is regarded as one of 
the best choices for low-cost bioenergy production in Europe [59]. It requires the minimum amount of nutrients and its cultivation is perceived as an advantageous way to use soils of low usability for food crop growing [60]. Willow can be grown on many types of agricultural land as it is highly tolerant of environmental conditions, with wetlands being preferred for this purpose [61-63]. Szczukowski et al. [64] demonstrated the potential for willow biomass production on excessively damp soil with a high groundwater table level. Salix viminalis can grow even when the soil profile is filled with water [65].

The present study showed that the commune of Goworowo has the right environmental conditions for growing perennial energy crops. There are 147 ha of usable marginal soils, with half of them being excessively humid and suitable for basket willow cultivation. The other half are sandy soils with a low groundwater table intended for giant miscanthus plantations. Based on the result of long-term experiments conducted by the University of Warmia and Mazury in Olsztyn [57,66], annual harvest rotations were used for the calculations. Based on the cited studies, it was assumed that willow and miscanthus would yield 15 and $12 \mathrm{Mg} \mathrm{ha}^{-1} \mathrm{y}^{-1}$ of fresh biomass, respectively. The corresponding LHV was 8 and $12 \mathrm{GJ} \mathrm{Mg}^{-1}$, respectively. It should be noted that the yield depends on the soil and weather conditions, planting density and agricultural procedures. The energy potential of biomass from energy crop plantations for annual harvest rotations is (10):

$$
\mathrm{Q}_{\mathrm{E}}=\mathrm{A}_{\mathrm{E}} \cdot \mathrm{Y}_{\mathrm{E}} \cdot \mathrm{LHV}
$$

where:

$\mathrm{Q}_{\mathrm{E}}$ - energy potential of biomass from Salix viminalis and Miscanthus $\times$ giganteus energy crops (GJ year ${ }^{-1}$ ),

$\mathrm{A}_{\mathrm{E}}$ - energy crops area (ha),

$\mathrm{Y}_{\mathrm{E}}$-assumed average annual yield of fresh biomass $\left(\mathrm{Mg} \mathrm{ha}^{-1} \mathrm{y}^{-1}\right)$,

LHV-lower heating value (GJ $\left.\mathrm{Mg}^{-1}\right)$.

\subsubsection{Hay from Meadows and Pastures}

The high biodiversity of semi-natural grasslands can be maintained only by continuous management. The hay yield from meadows in Poland amounts to $4.9 \mathrm{Mg} \mathrm{ha}^{-1} \mathrm{y}^{-1}$ and from pastures to $3.6 \mathrm{Mg} \mathrm{ha}^{-1} \mathrm{y}^{-1}$ [67]. The demand for pasture fodder, hay and silage for ruminants is decreasing, which is why a surplus can be used as energy feedstock [68-70]. The demand for fodder from grasslands in Poland is dropping due mainly to the changing system of farm animal (mainly cattle) feeding and the decreasing profitability of their breeding with the following reduction of their stock. As a result, many meadows and pastures remain unused and the limited extent of their use causes damage to nature (e.g., soil degradation) and economic loss (unused production potential). Hay from grassland is a considerable biomass resource which can be used as energy feedstock [71,72]. It is noteworthy that biomass from unused grassland for energy generation may prevent its natural succession [73]. It is recommended that cattle grazing in pastures be replaced with mowing to maintain and increase biodiversity, with no interference in traditional management methods (e.g., no fertilizers). Hay produced in this way can also be used as energy feedstock [74].

Semi-natural mesophilic mesotrophic grassland dominates in the commune of Goworowo. The meadows are used extensively, with two cuts annually, and virtually all hay is used in animal breeding. However, some farms were found to harvest three cuts while other farms mowed pastures in the face of insufficient amounts of hay or silage. Therefore, it was assumed that three instead of two cuts could be obtained from $5 \%$ of the meadows, and the surplus produced amounting to $2 \mathrm{Mg} \mathrm{ha}^{-1}$ year $^{-1}$ could be used as energy feedstock $[75,76]$. The potential of hay from meadows was calculated with the lower heating value taken as $13.5 \mathrm{GJ} \mathrm{Mg}^{-1}$ [77] (11). The assumed yield was regarded as the amount of hay obtained from mowing and collection, including possible baling.

$$
\mathrm{Q}_{\mathrm{M}}=0.05 \cdot \mathrm{A}_{\mathrm{M}} \cdot \mathrm{S}_{\mathrm{H}} \cdot \mathrm{LHV}
$$


where:

$\mathrm{Q}_{\mathrm{M}}$ - energy potential of hay from meadows $\left(\mathrm{GJ} \mathrm{y}^{-1}\right)$,

0.05-share of area, which can be used for energy purposes,

$\mathrm{A}_{\mathrm{M}}$ - area of meadows (ha),

$\mathrm{S}_{\mathrm{H}}$-surplus hay $\left(\mathrm{Mg} \mathrm{ha}^{-1} \mathrm{y}^{-1}\right)$,

LHV-lower heating value $\left(\mathrm{GJ} \mathrm{Mg}^{-1}\right)$.

It was also assumed that $5 \%$ of pastures are not fully used (excluding fallows) and one cut of hay can be obtained annually as energy feedstock. The annual average energy potential of hay from pastures was taken as $50 \mathrm{GJ} \mathrm{ha}^{-1}$ year $^{-1}[68,74]$ and it was included in the Equation (12). Late cut biomass from pastures can be used, which is beneficial as late swath is more flexible than early because of the weather conditions. Moreover, the hay quality had not deteriorated much by that time [70].

$$
\mathrm{Q}_{\mathrm{P}}=0.05 \cdot \mathrm{A}_{\mathrm{P}} \cdot \mathrm{E}_{\mathrm{P}}
$$

where:

$\mathrm{Q}_{\mathrm{P}}$ - total energy potential of hay from pastures $\left(\mathrm{GJ}^{-1}\right)$,

0.05-share of area, which can be used for energy purposes,

$A_{P}$-area of pastures (ha),

$\mathrm{E}_{\mathrm{p}}$ - energy potential of hay from pastures $\left(\mathrm{GJ} \mathrm{ha} \mathrm{h}^{-1} \mathrm{y}^{-1}\right)$.

\subsubsection{Landfilled Sludge and Municipal Waste}

The possibility of using landfilled sludge and municipal biodegradable waste produced in the commune was analyzed. Sludge surplus will make it necessary to seek new solutions for its proper management and use [78]. Currently, fluidized bed technologies enable thermal conversion of mechanically dehydrated or partially dried sludge [79]; co-combustion of dehydrated (not dried) sludge is possible, e.g., in CHPs [80]. The importance of sludge from rural wastewater also increases as it does not contain excessive amounts of heavy metals [81], which is the case with sludge from heavily industrialized areas [82]. Mechanical-biological wastewater treatment of communal wastewater in 2019 produced $51 \mathrm{Mg}$ (expressed as dry weight) of hydrated non-stabilized sludge (excessive sludge) [83], and $41 \mathrm{Mg}$ of the sludge was transported to Ostrołeka where it was subjected to anaerobic stabilization followed by mechanical dehydration (the sludge was not dried-the construction of a drier is planned [84]). Ten megagrams of sludge was stored in the commune [83]. Collected municipal waste-apart from mixed waste-included biodegradable waste, comprising mainly tree branches and shrub branches, sawdust and bark, mowed grass, leaves, flowers, fruit and vegetable waste. A total of 1,454.98 $\mathrm{Mg}$ of mixed municipal waste and $10.76 \mathrm{Mg}$ of biodegradable waste was collected from households in the commune in 2019 [85]. The biodegradable fraction accounts for $48 \%$ of the mixed municipal waste in rural areas [86]. The biodegradable waste amount was determined, assuming that it comprised the biodegradable fraction mentioned above (13).

$$
\mathrm{M}_{\mathrm{T}}=\mathrm{M}_{\text {Bio }}+0.48 \mathrm{M}_{\mathrm{M}}
$$

where:

$\mathrm{M}_{\mathrm{T}}$ - total mass of biodegradable waste $\left(\mathrm{Mg}^{-1}\right)$,

$\mathrm{M}_{\text {Bio }}$ - mass of biodegradable fraction $\left(\mathrm{Mg}^{-1}\right)$,

0.48 - factor taking into account share of biodegradable fraction in mixed waste,

$\mathrm{M}_{\mathrm{M}}$-mass of mixed waste $\left(\mathrm{Mg}^{-1}\right)$.

\section{Results and Discussion}

\subsection{Straw Potential}

Given the local conditions in the commune of Goworowo, the mass of straw as energy feedstock amounted to $2663 \mathrm{Mg} \mathrm{y}^{-1}$ (Table 4). It was a small amount, as it accounted 
for only $0.05 \%$ of the straw energy resources in Poland (5.1 million $\mathrm{Mg}^{-1}$ ) [21]). However, it accounted for the largest part (38.18\%) of the local solid biomass energy potential, $37,288 \mathrm{GJ} \mathrm{y}^{-1}$ (Table 4, Figure 2). Moreover, maintaining food supply and soil quality while acquiring the straw necessary to replace fossil fuels is of key importance (straw use for energy generation is enabled by pellet or briquet technology) $[87,88]$. For this reason, the current study (quantitatively determining energy potential) took into account the straw residue depending on its use in agriculture-as straw for fodder, for bedding or to be ploughed under.

Table 4. The amount and energy potential of each solid biomass type.

\begin{tabular}{|c|c|c|}
\hline Solid Biomass & Amount $\left(\mathrm{Mg}^{-1}\right)$ & $\begin{array}{l}\text { Theoretical Energy Potential } \\
\qquad\left(\mathrm{GJ} \mathrm{y}^{-1}\right)\end{array}$ \\
\hline Straw surplus & 2663 & 37,288 \\
\hline Residue from orchards & 23 & 180 \\
\hline Hay & 475 & 6543 \\
\hline Plantations of energy crops & 1985 & 19,404 \\
\hline Logging residue & $4553^{\mathrm{a}}$ & 34,144 \\
\hline Roadside wood & 14 & 113 \\
\hline Biodegradable waste & $709^{b}$ & - \\
\hline Landfilled sludge & $10^{c, b}$ & - \\
\hline Total & - & 97,672 \\
\hline
\end{tabular}

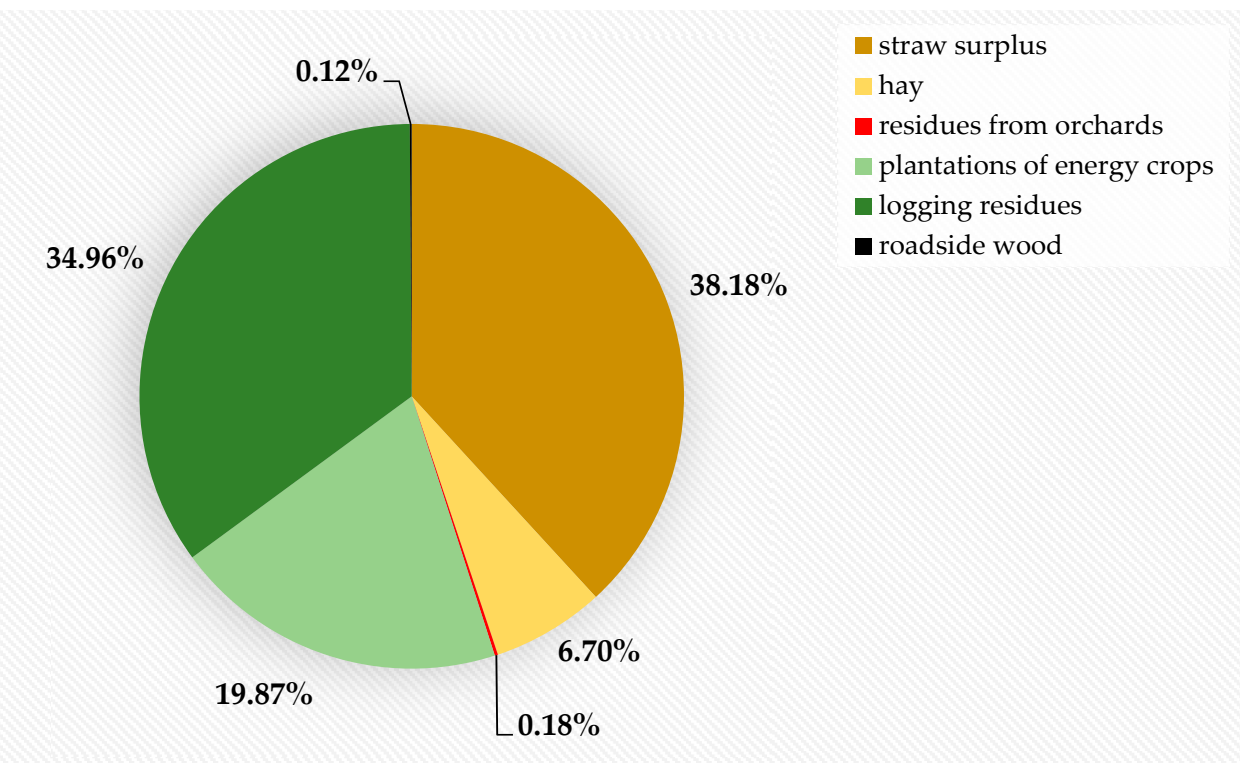

Figure 2. The proportion of individual solid biomass resources in the total energy potential of the commune of Goworowo (\%).

Crop production diversity in the commune of Goworowo was not high because of the soil and climate conditions, with the local straw resources most affected by triticale, wheat, cereal mixes and rye, in accordance with their cultivation area. Managing crop residue is particularly important for biomass utilization and energy generation for solving environmental problems and using alternative energy sources. More importantly, the cereal production continuity ensures the permanent availability of straw resources, whose overproduction is caused by a decreasing number of farm animals with an increasing proportion of cereals in the structure of crops [20,22]. 
Cereal straw resources are regarded as the greatest unused energy potential in agriculture. Unlike the area used for the cultivation of rape and turnip-like rape in the Mazovian Voivodship, the area that was used for cereal cultivation has been growing in recent years. Since the yield per ha of cereals as well as rape and turnip-like rape is continuously increasing [89], the straw energy potential in the commune of Goworowo is expected to increase, or at least to remain unchanged.

\subsection{Orchard Potential}

The estimated energy wood resources from orchards in Poland amount to $88,700 \mathrm{Mg} \mathrm{y}^{-1}$ [90]. The small orchards area in the agricultural land in the commune of Goworowo-merely 21.96 ha-resulted in a small orchard wood biomass amount, i.e., $23 \mathrm{Mg} \mathrm{y}^{-1}$ (Table 4). The orchard waste energy potential amounted to $180 \mathrm{GJ}^{-1}$, which accounted for merely $0.18 \%$ of the total (Figure 2 ). The biomass obtained by pruning fruit trees was often used in households, but this applies mainly to biomass from backyard gardens. The energy potential of the considerable amounts of waste from typical orchards is usually lost due to storing or burning it in the field [91], while it could be used as fuel [22]. Proper management of these resources may increase the effectiveness of biomass use in the future, as orchard biomass waste used for energy generation does not compete with food production [92], which may be the case with cereal straw or hay.

Moreover, pollution emissions from burning pruned biomass in appropriate boilers are low [92]. However, the orchard area in the commune decreased by over half over the 2017-2020 period [23,93] and the orchard area also decreased in the Mazowieckie Voivodship (by over 1100 ha over the 2017-2020 period) [30,94-96]. Therefore, the local resources of this biomass source are likely to decrease in future, especially given the drop in the proportion of fruit trees in orchards in the voivodship, which are being replaced by bushes and berry plantations [89,97].

It should be noted that pruning waste cannot always be used for energy production, although its impact on the greenhouse effect is smaller than in situ mulching. This happens when the absence of plant cover in the inter-row space exceeds $80 \%$ and the soil structure has a tendency for compaction, for becoming muddy or for surface runoff, and when the orchard is susceptible to erosion. The ground biomass should be mulched in the first and second case and ploughed under in the third. The local potential cannot then be fully utilized [98].

\subsection{Forest Potential}

Local resources of forest residues biomass in the commune of Goworowo were determined as $4553 \mathrm{~m}^{3} \mathrm{y}^{-1}$, which was equivalent to the energy potential of $34,144 \mathrm{GJ}^{-1}$ (34.96\% of the whole) (Table 4, Figure 2). The annual increment ratio was assumed at the level given for Poland-74.8\% [48], although it was 116\% in the Pułtusk Forest District and $114 \%$ in the Wyszków Forest District $[43,44]$. The wood harvest in a calendar year depends on the area ratio of the final cutting sites to intermediate cutting sites. The energy potential of logging residue largely depends on the development phase of the forests in the area. When final cutting sites (with much thicker and slower growing trees than in intermediate cutting sites) dominate the forest structure, the harvest-to-increment ratio can exceed 100\% and the logging residue amount then increases considerably. However, these indices are given for a whole forest district area and they do not provide data for individual communes. There are also data for 10 year periods, which is why a lower value was adopted to avoid overestimating the local resources.

The optimum wood amounts to be left in local forests should be determined to maintain biodiversity and conserve forest ecosystems. Perceiving the forest as a source of energy feedstock must be accompanied by ecological thinking [1]. Taking this factor into account in research is called "potential with increased biodiversity conservation" [99]. It is important because the forest area in Europe with satisfactory amounts of deadwood has been very small during the past few decades [100]. 
The forest area in the commune of Goworowo was larger in 2020 compared to 2017 by over 1000 ha, i.e., by 16\% [23,93]. This increase reflects the increasing forestation level in Poland [101] and ensures the stability of forest residues as a source of solid biomass. The issues related to forest management are often left out of development strategies, due to which forests are not regarded as a factor of the region's socio-economic development [102]. Mentioning the bioenergy aspects of forests in strategic documents may prevent its marginalization in the political spheres and increase society's interest in it.

\subsection{Roadside Potential}

Roadside maintenance produces biomass for bioenergy generation, but only a small part of it is used due to dispersion [103]. This study has shown that roadsides in the commune of Goworowo constitute a local space concerning the solid biomass energy potential. About $14 \mathrm{Mg}$ of wood biomass, with an energy potential of $113 \mathrm{GJ} \mathrm{y}^{-1}$, can be obtained from the roadsides in the commune (Table 4). The presence of trees on roadsides ensures that biomass can be acquired by pruning, which is usually wasted [104]. The potential in this regard also increases as the process may contribute to roadside naturalization when the biomass of an invasive species is obtained, which can be replaced by native flora, thereby improving biodiversity [105].

A better choice of tree species and developing more diverse resources improves the ecosystem advantages provided by roadsides [106]. Managing wood from roadsides provides more benefits, e.g., ensuring the patency of roadside draining ditches [105]. Roads must be accessible to society, be convenient and safe, and integrate with their surroundings. Their development is accompanied by an increase in the roadside area, which connects forests, farms and traffic networks. The main purpose of roadside management is to ensure traffic safety (improving visibility and providing a space for emergency stops). It can produce biomass from tree and bush pruning, which can be used as fuel to maintain a positive energy balance. The promotion of ecosystem services from roadsides is a future line of sustainable management in such areas [105-107]. Growing urbanization will increase the roadside area, which makes proper management crucial. The roadside wood potential can help transition from conventional road management to a form based on a circular economy [105]. Even leaves from roadside trees can be used in the production of high-quality solid biofuels [108].

\subsection{Potential of Perennial Energy Crops}

The land in the commune of Goworowo allocated for perennial energy crop plantations could yield $1103 \mathrm{Mg}$ of fresh willow biomass and $882 \mathrm{Mg}$ of fresh miscanthus biomass annually (Table 4). The total energy potential of the plantations was $19,404 \mathrm{GJ}^{-1}$, accounting for $19.87 \%$ (Figure 2). Only $1.5 \%$ of arable land was proposed for the plantations in the current study, and all of it belonged to the poorest quality class (class V and VI). Currently, winter rye and serradella are grown on the poorest quality soil in the commune and the cultivation effectiveness is low. Growing perennial energy crops on such soils, where the nutrient abundance is low, where biophysical restrictions exist and where the crop yield is low, is a more sustainable alternative than traditional food crops [109]. Since competition in soil used for food crop production requires spatial land segregation [110], choosing the poorest quality soils with the lowest effectiveness in food crop cultivation was justified. Growing perennial crops on this land could improve the soil properties by increasing its total organic carbon content, and decreasing its susceptibility to erosion $[109,110]$.

Sustainable development stimulates an interest in bioenergy generation from renewable sources, and biofuel production from energy crops in Europe is expected to grow to meet the policy goals (The European Green Deal) [5,111]. Energy crops in Poland are grown in an area of approximately 17,900 ha [21]. No such plantations exist in the commune of Goworowo, even though it has appropriate potential for them. The use of 143 ha of marginal land for this purpose could considerably increase lignocellulosic biomass produc- 
tion, especially since Poland is one of the major producers of SRC willow in Europe [61]. The crop species chosen for the commune of Goworowo-miscanthus and willow-are among the main candidates for lignocellulosic crop plantations in Europe. Their impact on biodiversity in the field is often regarded as beneficial compared to conventional food crops [112]. A similar impact is also expected in the commune as agricultural land was selected for such plantations, while permanent grassland and wasteland with high biodiversity (part of which is protected under the NATURE 2000 program) were excluded.

\subsection{Potential of Permanent Grassland}

The commune had a large area of permanent grassland—over 3327 ha-which can be used for energy generation despite some limitations connected with animal breeding [23]. The possibilities of the annual hay harvest amounted to $475 \mathrm{Mg}$ of hay (321 Mg from pastures and $154 \mathrm{Mg}$ from meadows) annually with an energy potential of $6543 \mathrm{GJ}$ (4460 GJ from pastures and $2083 \mathrm{GJ}$ from meadows) (Table 4). The difference in biomass yield from pastures and meadows was a consequence of local conditions. The meadows were mainly used extensively, not only at Nature 2000 sites but all over the commune. Therefore, increasing the number of cuts from two to three gave a surplus which could be used as fuel. Many pastures were not used to the full extent, reflecting the situation around the country, where most pastures are not used because of the drop in the farm animal stock [67].

Apart from the considerable benefits of using the hay surplus, certain difficulties are connected with obtaining it. These resources are not often easily accessible (wetlands) and their quality varies, depending on the moisture and mineral content [22]. Since the commune of Goworowo is situated in two NATURE 2000 Special Bird Protection sites—Dolina Dolnej Narwi PLB140014 and Puszcza Biała PLB140007-the grassland in them has to be mowed to maintain the bird populations covered by the Birds Directive. Abandoning the mowing results in natural succession and biocenotic evolution and poses a threat to the objects of protection in the commune. Mowing can prevent it, especially since protective measures include removing the produced biomass $[113,114]$. The permanent grassland area has been decreasing in recent years, both in the Mazowieckie Voivodship and in Poland $[89,115,116]$. The hay resources in the commune under study are expected to stay at the same level since they have remained unchanged over the years $[23,93]$.

\subsection{Potential of the Landfilled Sludge and Municipal Waste}

The analysis has shown that the sludge landfilled in the commune of Goworowo (10 Mg of dry weight) is stored only to recirculate to bioreactors when biogenic elements for microorganisms are absent (Table 4). Therefore, its storage helps to maintain the continuity of the wastewater treatment process. The sludge was therefore excluded as a potential source of solid biomass. There is $165,000 \mathrm{Mg} \mathrm{y}^{-1}$ of municipal sludge in Poland intended for energy recovery by combustion [21]. Typical stabilized and dehydrated sludge has a calorific value of approximately $0.5 \mathrm{GJ} \mathrm{Mg}^{-1}$ [117], which increases to $11 \mathrm{GJ} \mathrm{Mg}^{-1}$ after drying [118]. Any surplus of recirculated sludge from the commune of Goworowo which was not utilized in agriculture can be used for thermal conversion.

The annual production of biodegradable waste in the commune amounted to $709 \mathrm{Mg}$, but all of it was collected by external companies and transported to municipal waste processing installations (Table 4). In future, determination of the biodegradable waste potential will require an analysis of what part of mixed and separately collected municipal waste is stored despite being intended for processing and the acquisition of data on its amount. Annually, 2,724,000 Mg of waste is used as an energy source in Poland [21]. Potential biodegradable/green waste in the commune could be used for thermal conversion with energy recovery or biogas plant feedstock, increasing the RES use indices.

\subsection{Commune Potential}

The total energy potential of solid biomass resources in the commune of Goworowo amount to $97,672 \mathrm{GJ} \mathrm{y}^{-1}$ (Table 4). The amounts of individual types of solid biomass and 
their potential varied significantly, which resulted from the local conditions. The solid biomass resources in the commune were equivalent to $4192 \mathrm{Mg}$ of hard coal (the most commonly used heat source in the commune), assuming its calorific value of $23.3 \mathrm{GJ} \mathrm{Mg}^{-1}$ (for eco-pea coal) [36] (Figure 3). This shows that the solid biomass potential in the commune of Goworowo is high. Surplus straw accounted for the greatest part and wood from roadside maintenance accounted for the smallest part of the energy potential in the commune (Figure 3).

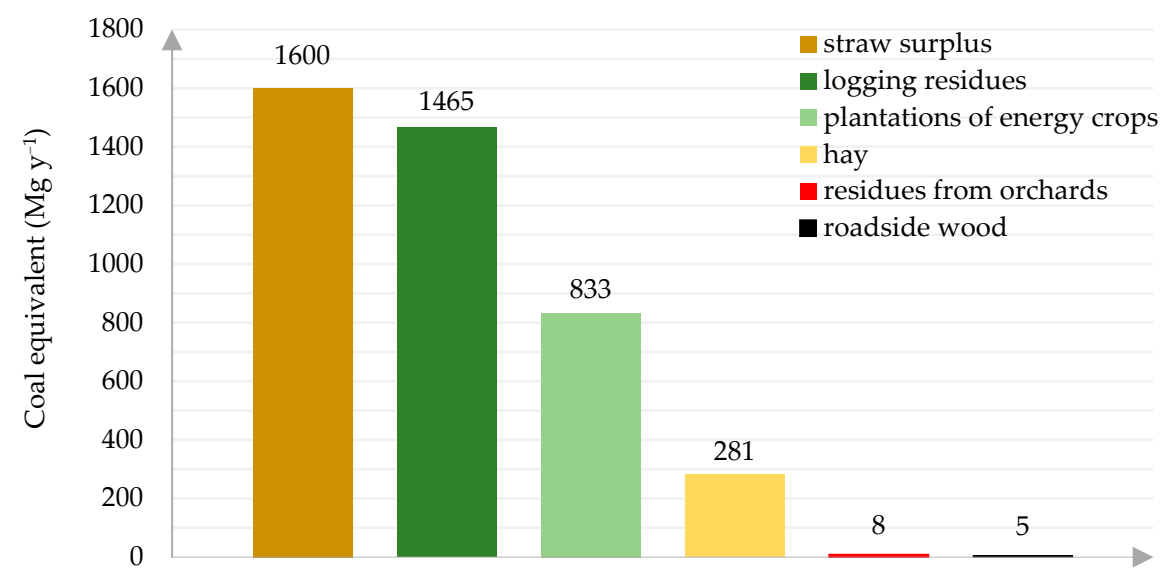

Figure 3. The potential of energy accumulated in solid biomass resources expressed as the coal equivalent $\left(\mathrm{Mg} \mathrm{y}^{-1}\right)$.

Kowalczyk-Juśko et al. [22] determined the energy potential of the Bialski District in the southeast of Poland, where the energy potential of communes ranged from 7690 to $707,933 \mathrm{GJ}^{-1}$. However, that study also included solid biomass residues from wood industry facilities. It was not mentioned in the current research as there is no such facility in the commune. Moreover, the Bialski District is one of the three largest districts in Poland [119]. Moreover, 10\% of marginal arable soils and permanent grassland were allocated for energy crop plantations in the majority of the communes in the cited research [22], whereas in the current study, it was only $1.5 \%$ arable land, all belonging to the poorest quality. However, the current findings for the commune of Goworowo confirm that the smallest territorial units (communes) have large solid biomass resources, which can (and should) be of great importance in satisfying energy needs, especially as fuel in local boilers and for individual recipients.

A high value of solid biomass must also be emphasized as referring to the price of hard coal (eco-pea coal). The retail price of this fuel, depending on its origin and quality, ranged from EUR $146 \mathrm{Mg}^{-1}$ to even more than EUR $225 \mathrm{Mg}^{-1}$ (average PLN/EUR exchange rate in 2020-4.4448/1.0). Assuming the average eco-pea coal price of EUR $180 \mathrm{Mg}^{-1}$, the value of energy accumulated in solid biomass, referred to as the eco-pea coal price, amounted to EUR 754,487 $\mathrm{y}^{-1}$. Therefore, this is a high value when referred to the scale of the commune of Goworowo, which can potentially be used continuously for many years. It is particularly important from the point of view of the local supply of energy feedstock. There are no fossil fuel resources in the commune of Goworowo, so all the money spent to purchase it flows out of the commune and often out of the country. When biomass is used as an energy feedstock, the money for the biofuel remains in the commune, in local circulation. Owing to this system, the entities producing fuel or energy from biomass have funds for investment and development and can employ new personnel in the RES industry, which contributes to local development. Therefore, biomass use as energy feedstock can result in continuous stimulation for the infrastructure development in rural areas and can help to implement modern technologies of biomass conversion to energy and, in future, to various high-value bioproducts. This issue is extremely important as biomass-as feedstock, and unlike other RES-requires the involvement of many entities 
to organize the whole logistics chain, from production and acquisition of biomass, through to its storage, warehousing, transport, preparation for technological processes, conversion and final use. Therefore, one can say that — unlike other RES_-biomass is a "demanding" fuel. However, paradoxically, this demanding energy feedstock can provide a positive development stimulus for the commune and the region since it engages a considerable workforce.

\section{Conclusions}

Much research into local biomass potential is needed to connect its management effectively with the development of renewable energy sources. This is of particular importance for further development of research in this domain and the subsequent application of the results in science and practice. Firstly, the current study shows that the smallest administrative unit in Poland-a rural commune-has solid biomass resources with considerable energy and financial potential for use. Secondly, the study also emphasizes the challenges, such as sustainable management of local solid biomass resources, taking into account the protection of biodiversity and the environment, e.g., the role of the space where solid biomass is present as a natural habitat. Thirdly, it was demonstrated that the commune could be a place where energy sources are diversified and where links are created between the economy and ecology by obtaining biomass. Fourthly, research should be continued to determine the technical potential of biomass resources and the link between local development and local community welfare.

Rural areas, such as the commune of Goworowo that has an agriculture and forestry sector in its area, could soon play a major role in producing and using solid biomass. Local communities and fragmented farms, which do not develop on an industrial scale, could be provided with many opportunities. Further research is also necessary in this field. Local communities must be given information on the resources in their area and about their value. They must be informed about effective technologies and their use and cost-effective logistics and management systems.

Moreover, policymakers and local governments should undertake appropriate measures to allow for the most effective use of these local resources. However, this study also has some limitations since it refers to a single commune existing under certain geographic and demographic conditions. Furthermore, it is necessary to have access to reference data to identify specific local features, which may be diverse even for neighboring communes.

Author Contributions: Conceptualization, M.J.S. and P.D.; methodology, M.J.S. and P.D.; validation, M.J.S., E.O.-Z. and M.K.; formal analysis, M.J.S., P.D., M.K. and E.O.-Z.; investigation, M.J.S., P.D., M.K. and E.O.-Z.; data curation, M.J.S. and P.D.; writing-original draft preparation, M.J.S. and P.D.; writing-review and editing, M.J.S., M.K. and E.O.-Z.; visualization, P.D.; supervision, M.J.S.; project administration, M.J.S. All authors have read and agreed to the published version of the manuscript.

Funding: The results presented in this paper were obtained as part of a comprehensive study financed by the University of Warmia and Mazury in Olsztyn, Faculty of Agriculture and Forestry, Department of Genetics, Plant Breeding and Bioresource Engineering (grant No. 30.610.007-110) and has been co-financed by the Interreg Baltic Sea Region Programme 2014-2020 co-funded by the European Regional Development Fund under the project "Unlocking the Potential of Bio-based Value Chains in the Baltic Sea Region" (BalticBiomass4Value-BB4V), No. \#R095 and co-financed from the funds of the Ministry of Science and Higher Education under the program "PMW" in the years 2019-2021; No. 5047/INTERREG BSR/2019/2.

Acknowledgments: We would like to thank the staff of the Goworowo Municipal Office for providing the necessary information for the preparation of this manuscript.

Conflicts of Interest: The authors declare no conflict of interest. 


\section{References}

1. Kluczkowski, A. The use of wood biomass in the regional system of renewable energy sources as a chance for the region. J. Vasyl Stefanyk Precarpathian Natl. Univ. 2017, 4, 67-73. [CrossRef]

2. Rosales-Calderon, O.; Arantes, V. A review on commercial-scale high-value products that can be produced alongside cellulosic ethanol. Biotechnol. Biofuels 2019, 12, 240. [CrossRef]

3. Brodny, J.; Tutak, M.; Saki, S.A. Forecasting the structure of energy production from renewable energy sources and biofuels in Poland. Energies 2020, 13, 2539. [CrossRef]

4. Marks-Bielska, R.; Bielski, S.; Pik, K.; Kurowska, K. The importance of renewable energy sources in Poland's energy mix. Energies 2020, 13, 4624. [CrossRef]

5. Brodny, J.; Tutak, M. Analyzing similarities between the european union countries in terms of the structure and volume of energy production from renewable energy sources. Energies 2020, 13, 913. [CrossRef]

6. Sefeedpari, P.; Pudełko, R.; Jędrejek, A.; Kozak, M.; Borzęcka, M. To what extent is manure produced, distributed, and potentially available for bioenergy? A step toward stimulating circular bio-economy in Poland. Energies 2020, 13, 6266. [CrossRef]

7. Statistics Poland. Energy from Renewable Sources in 2018. 2019. Available online: https://stat.gov.pl/obszary-tematyczne/ srodowisko-energia/energia/energia-ze-zrodel-odnawialnych-w-2018-roku,10,2.html (accessed on 12 February 2021).

8. Eurostat. Energy Data-2020 Edition. 2020. Available online: https:/ / ec.europa.eu/eurostat/web/products-statistical-books/- / KS-HB-20-001 (accessed on 13 February 2021).

9. Statistics Poland. Energy Statistics in 2018 and 2019. 2020. Available online: https://stat.gov.pl/obszary-tematyczne/srodowiskoenergia/energia/gospodarka-paliwowo-energetyczna-w-latach-2018-i-2019,4,15.html (accessed on 12 February 2021).

10. Eurostat. 2019. Available online: https:/ / ec.europa.eu/eurostat/data/statistics-a-z/abc (accessed on 2 April 2021).

11. Statistics Poland. Energy from Renewable Sources in 2019. 2020. Available online: https://stat.gov.pl/obszary-tematyczne/ srodowisko-energia/energia/energia-ze-zrodel-odnawialnych-w-2019-roku,3,14.html (accessed on 2 April 2021).

12. Stolarski, M.J.; Warmiński, K.; Krzyżaniak, M.; Olba-Zięty, E.; Stachowicz, P. Energy consumption and heating costs for a detached house over a 12-year period-Renewable fuels versus fossil fuels. Energy 2020, 204, 117952. [CrossRef]

13. Vezzoli, C.; Ceschin, F.; Osanjo, L.; M’Rithaa, M.K.; Moalosi, R.; Nakazibwe, V.; Diehl, J.C. Distributed/decentralised renewable energy systems. In Designing Sustainable Energy for All, 1st ed.; Vezzoli, C., Ceschin, F., Osanjo, L., M'Rithaa, M.K., Moalosi, R., Nakazibwe, V., Diehl, J.C., Eds.; Springer: Cham, Switzerland, 2018; pp. 23-39.

14. Kluczkowski, A.; Wyrostkiewicz, M. Circular economy as an important subject of environmental education in the era of energy demand. J. Vasyl Stefanyk Precarpathian Natl. Univ. 2018, 5, 88-94. [CrossRef]

15. Statistics Poland. Area and Population in the Territorial Profile in 2020. 2020. Available online: https://stat.gov.pl/obszarytematyczne/ludnosc/ludnosc/powierzchnia-i-ludnosc-w-przekroju-terytorialnym-w-2020-roku,7,17.html (accessed on 14 March 2021).

16. Kaczmarek, T. Communal administrative division in the light of 25 years of operation of local government in Poland. Political Sci. Rev. 2016, 1, 63-80.

17. Rokicki, T.; Perkowska, A.; Klepacki, B.; Bórawski, P.; Bełdycka-Bórawska, A.; Michalski, K. Changes in energy consumption in agriculture in the EU countries. Energies 2021, 14, 1570. [CrossRef]

18. Rocha-Meneses, L.; Bergamo, T.F.; Kikas, K. Potential of cereal-based agricultural residues available for bioenergy production. DataBrief 2019, 23, 103829. [CrossRef] [PubMed]

19. Steubing, B.; Zah, R.; Waeger, P.; Ludwig, C. Bioenergy in Switzerland: Assessing the domestic sustainable biomass potential. Renew. Sustain. Energy Rev. 2010, 14, 2256-2265. [CrossRef]

20. Avcıŏ̆lu, A.O.; Dayığlu, M.A.; Türker, U. Assessment of the energy potential of agricultural biomass residues in Turkey. Renew. Energy 2019, 138, 610-619. [CrossRef]

21. Stolarski, M.J.; Warmiński, K.; Krzyżaniak, M.; Olba-Zięty, E.; Akincza, M. Bioenergy technologies and biomass potential vary in Northern European countries. Renew. Sustain. Energy Rev. 2020, 133, 110238. [CrossRef]

22. Kowalczyk-Juśko, A.; Listosz, A.; Mazur, K.; Macig, M.; Pochwatka, P.; Mazur, A. The state and the perspectives of the eco-energy infrastructure development in Biała Podlaska County (Poland). Part II Estimation of solid biomass resources for energy purposes. E3S Web Conf. 2020, 171, 01005. [CrossRef]

23. Mayor of the Goworowo Commune. Report on the State of the Goworowo Commune. 2020. Available online: http:/ /goworowo. pl/wp-content/uploads/2020/05/Goworowo_raport_o_stanie_gminy_2019.pdf (accessed on 21 January 2021).

24. Poland's Open Data Portal. Open Spatial Data Geoportal. 2021. Available online: https://polska.e-mapa.net/ (accessed on 2 April 2021).

25. Statistics Poland. Statistical Vademecum of a Local Government. 2020. Available online: https://warszawa.stat.gov.pl/ statystyczne-vademecum-samorzadowca/ (accessed on 12 March 2021).

26. Mayor of the Goworowo Commune. Environmental Protection Program for the Goworowo Commune. 2019. Available online: http:/ /goworowo.pl/wp-content/uploads/2019/09/Program-Ochrony-\%C5\%9Arodowiska.pdf (accessed on 20 January 2021).

27. Mayor of the Goworowo Commune. The Basic Ecophysiographic Study Prepared for the Needs of Study of the Conditions and Directions of Spatial Development in the Commune of Goworowo (Local Document Provided by the Goworowo Commune Office on Request); Goworowo Commune Office: Goworowo, Poland, 2013. 
28. Marshal's Office of the Mazowieckie Voivodeship. Spatial Information System for the Mazowieckie Voivodeship. 2021. Available online: https:/ / msip.wrotamazowsza.pl/msip/Full.aspx (accessed on 13 January 2021).

29. Statistics Poland. Land Use and Sown Area in 2019. 2020. Available online: https://stat.gov.pl/obszary-tematyczne/rolnictwolesnictwo/rolnictwo/uzytkowanie-gruntow-i-powierzchnia-zasiewow-w-2019-roku,8,15.html (accessed on 7 December 2020).

30. Marshal's Office of the Mazowieckie Voivodeship. A Summary of the Data from the Land and Building Register of the Mazowieckie Voivodship. 2019. Available online: https://gis.wrotamazowsza.pl/bezplatne-dane/ (accessed on 7 December 2020).

31. Minister of Investment and Development. The Ordinance on Land and Building Register. 2019. Available online: https: / / isap.sejm.gov.pl/isap.nsf/DocDetails.xsp?id=WDU20190000393 (accessed on 7 December 2020).

32. Statistics Poland. The Resulting Estimate of the Main Agricultural and Horticultural Crops. 2020. Available online: https:/ / stat.gov.pl/obszary-tematyczne/rolnictwo-lesnictwo/uprawy-rolne-i-ogrodnicze/wynikowy-szacunek-glownychziemioplodow-rolnych-i-ogrodniczych-w-2020-roku,5,19.html (accessed on 11 January 2021).

33. Warmia and Mazury Agricultural Advisory Center. Review of Polish Maize Varieties. 2018. Available online: https://wmodr.pl/ files/tnUefXPeFS3uEU5QOPGyrGyiNp0JhC3jzRTxCAJz.pdf (accessed on 11 January 2021).

34. Hryniewicz, M.; Grzybek, A. Available straw surplus for use for energy purposes in 2016. Probl. Agric. Eng. 2017, 3, 15-31.

35. Bieranowski, J.; Olkowski, J. The concept of an energy self-sufficient farm system compatible with sustainable development in a selected region in Poland. Pol. J. Environ. Stud. 2016, 25, 529-544. [CrossRef]

36. Stolarski, M.J.; Rybczyńska, B.; Krzyżaniak, M.; Lajszner, W.; Graban, Ł.; Peni, D.; Bordiean, A. Thermophysical properties and elemental composition of agricultural and forest solid biofuels versus fossil fuels. J. Elem. 2019, 24, 1215-1228. [CrossRef]

37. Roman, M.; Roman, K. Energy use of wood waste from fruit trees on the example of an agritourism farm. Ann. Pol. Assoc. Agric. Agribus. Econ. 2018, XX, 158-161.

38. Dyjakon, A.; den Boer, J.; Bukowski, P.; Adamczyk, F.; Frąckowiak, P. Wooden biomass potential from apple orchards in Poland. Wood Res. Pap. Rep. Announc. 2016, 59, 73-86.

39. Cichy, W.; Witczak, M.; Walkowiak, M. Fuel properties of woody biomass from pruning operations in fruit orchards. BioResources 2017, 12, 6458-6470. [CrossRef]

40. Swithenbank, J.; Chen, Q.; Zhang, X.; Sharifi, V.; Pourkashanian, M. Wood would burn. Biomass Bioenergy 2011, $35,999-1007$. [CrossRef]

41. Statistics Poland. Statistical Yearbook of Forestry. 2020. Available online: https://stat.gov.pl/obszary-tematyczne/rocznikistatystyczne/roczniki-statystyczne/rocznik-statystyczny-lesnictwa-2020,13,3.html (accessed on 5 March 2021).

42. Forest District Ostrołęka. Forest Management Plan. 2012. Available online: https://bip.lasy.gov.pl/pl/bip/dg/rdlp_olsztyn/ nadl_ostroleka/plan_urzadzania_lasu/czesc_opisowa (accessed on 5 March 2021).

43. Forest District Pułtusk. Forest Management Plan. 2014. Available online: https://bip.lasy.gov.pl/pl/bip/dg/rdlp_warszawa/ nadl_pultusk/plan_urzadzania_lasu/czesc_opisowa (accessed on 5 March 2021).

44. Forest District Wyszków. Forest Management Plan. 2017. Available online: https://bip.lasy.gov.pl/pl/bip/dg/rdlp_warszawa/ nadl_wyszkow/plan_urzadzania_lasu/czesc_opisowa (accessed on 5 March 2021).

45. Gendek, A.; Wężyk, P.; Moskalik, T. Share and accuracy of estimation of logging residues in the total volume of harvested timber. Sylwan 2018, 162, 679-687.

46. Różański, H.; Jabłoński, K. Prospects for forest biomass harvesting for energy purposes in Poland. J. Civ. Eng. Environ. Archit. 2015, XXXII, 351-358. [CrossRef]

47. Order of the General Director of State Forests. Technical Conditions-Division, Terminology and Symbols Used in the Turnover of Wood Raw Material. 2019. Available online: http:/ / drewno.zilp.lasy.gov.pl/drewno/Normy/ (accessed on 6 March 2021).

48. National Forest Holding the State Forests. Report on the Condition of Forests in Poland. 2020. Available online: https://www.lasy. gov.pl/pl/informacje/publikacje/informacje-statystyczne-i-raporty/raport-o-stanie-lasow/raport-o-stanie-lasow.pdf/view (accessed on 6 March 2021).

49. Abolins, J.; Gravitis, J. Sustainable supply of energy from biomass. Latv. J. Phys. Tech. Sci. 2010, 47, 57-63. [CrossRef]

50. Voinov, A.; Arodudu, O.; Duren, I.; Morales, J.; Qin, L. Estimating the potential of roadside vegetation for bioenergy production. J. Clean. Prod. 2015, 102, 213-225. [CrossRef]

51. Oniszk-Popławska, A.; Krasuska, E. Energy from Organic Waste, 1st ed.; Research and Innovation Centre Pro-Akademia Branch of Polish Academy of Sciences: Łódź, Poland, 2014; pp. 1-48.

52. Act on Nature Conservation. Act of 16 April 2004, Journal of Laws 2020 Item 55. Available online: https://isap.sejm.gov.pl/isap. nsf/DocDetails.xsp?id=WDU20040920880 (accessed on 22 January 2021).

53. Jezierska-Thöle, A.; Rudnicki, R.; Kluba, M. Development of energy crops cultivation for biomass production in Poland. Renew. Sustain. Energy Rev. 2016, 62, 534-545. [CrossRef]

54. Blanco-Canqui, H. Growing dedicated energy crops on marginal lands and ecosystem services. Soil Sci. Soc. Am. J. 2016, 80, 845-858. [CrossRef]

55. Dubis, B.; Jankowski, K.J.; Załuski, D.; Sokólski, M. The effect of sewage sludge fertilization on the biomass yield of giant miscanthus and the energy balance of the production process. Energy 2020, 206, 118189. [CrossRef]

56. Dubis, B.; Jankowski, K.J.; Załuski, D.; Bórawski, P.; Szempliński, W. Biomass production and energy balance of Miscanthus over a period of 11 years: A case study in a large-scale farm in Poland. GCB Bioenergy 2019, 11, 1187-1201. [CrossRef] 
57. Stolarski, M.J.; Śnieg, M.; Krzyżaniak, M.; Tworkowski, J.; Szczukowski, S. Short rotation coppices, grasses and other herbaceous crops: Productivity and yield energy value versus 26 genotypes. Biomass Bioenergy 2018, 119, 109-120. [CrossRef]

58. Mehmood, M.A.; Ibrahim, M.; Rashid, U.; Nawaz, M.; Ali, S.; Hussain, A.; Gull, M. Biomass production for bioenergy using marginal lands. Sustain. Prod. Consum. 2017, 9, 3-21. [CrossRef]

59. Matyka, M.; Kuś, J. Influence of Soil Quality for Yielding and Biometric Features of Miscanthus x Giganteus. Pol. J. Environ. Stud. 2016, 25, 213-219. [CrossRef]

60. Shepherd, A.; Clifton-Brown, J.; Kam, J.; Buckby, S.; Hastings, A. Commercial experience with miscanthus crops: Establishment, yields and environmental observations. GCB Bioenergy 2020, 12, 510-523. [CrossRef]

61. Mantziaris, S.; Iliopoulos, C.; Theodorakopoulou, I.; Petropoulou, E. Perennial energy crops vs. durum wheat in low input lands: Economic analysis of a Greek case study. Renew. Sustain. Energy Rev. 2017, 80, 789-800. [CrossRef]

62. Pray, T.J.; Guidi Nissim, W.; St-Arnaud, M.; Labrecque, M. Investigating the effect of a mixed mycorrhizal inoculum on the productivity of biomass plantation willows grown on marginal farm land. Forests 2018, 9, 185. [CrossRef]

63. Matyka, M.; Radzikowski, P. Productivity and biometric characteristics of 11 varieties of willow cultivated on marginal soil. Agriculture 2020, 10, 616. [CrossRef]

64. Szczukowski, S.; Stolarski, M.; Tworkowski, J. Yield of willow biomass produced by the Eco-Salix system. Fragm. Agron. 2011, $28,104-115$.

65. Jurczuk, S.; Chrzanowski, S.; Jaszczyński, J. Yielding of the energy willow under differentiated soil-water conditions. Probl. Agric. Eng. 2010, 18, 113-121.

66. Stolarski, M.J.; Krzyżaniak, M.; Warmiński, K.; Olba-Zięty, E.; Penni, D.; Bordiean, A. Energy efficiency indices for lignocellulosic biomass production: Short rotation coppices versus grasses and other herbaceous crops. Ind. Crop. Prod. 2019, 135, 10-20. [CrossRef]

67. Igliński, B.; Buczkowski, R.; Cichosz, M. Biogas production in Poland-Current state, potential and perspectives. Renew. Sustain. Energy Rev. 2015, 50, 686-695. [CrossRef]

68. Melts, I.; Heinsoo, K.; Nurk, L.; Pärn, L. Comparison of two different bioenergy production options from late harvested biomass of Estonian semi-natural grasslands. Energy 2013, 61, 6-12. [CrossRef]

69. Ketzer, D.; Rösch, C.; Haase, M. Assessment of sustainable Grassland biomass potentials for energy supply in Northwest Europe. Biomass Bioenergy 2017, 100, 39-51. [CrossRef]

70. Boob, M.; Elsaesser, M.; Thumm, U.; Hartung, J.; Lewandowski, I. Harvest time determines quality and usability of biomass from lowland hay meadows. Agriculture 2019, 9, 198. [CrossRef]

71. Jarosz, Z. Energy potential of agricultural crops biomass and their use for energy purposes. Probl. World Agric. 2017, 17, 81-92.

72. Igliński, B.; Cichosz, M.; Skrzatek, M.; Buczkowski, R. Technical potential of waste biomass for energy in Poland. Eng. Prot. Environ. 2018, 22, 109-118. [CrossRef]

73. Lipińska, H.; Kurzepa, K.; Kościk, S. Economically unexploited permanent grassland in Chełm County as a potential source of biomass production for energy generation. Grassl. Sci. Pol. 2017, 20, 107-119.

74. Heinsoo, K.; Melts, I.; Holm, B. The potential of Estonian semi-natural grasslands for bioenergy production. Agric. Ecosyst. Environ. 2010, 137, 86-92. [CrossRef]

75. Agricultural Advisory Center in Brwinów. Rational Use of Grassland on an Ecological Farm. 2010. Available online: https: / / www.cdr.gov.pl/images / wydawnictwa/2010/2010-racjonalne-wykorzystanie-uzytkow-zielonych-w-gospodarstwieekologicznym.pdf (accessed on 16 January 2021).

76. von Cossel, M.; Bauerle, A.; Boob, M.; Thumm, U.; Elsaesser, M.; Lewandowski, I. The performance of mesotrophic arrhenatheretum grassland under different cutting frequency regimes for biomass production in southwest Germany. Agriculture 2019, 9, 199. [CrossRef]

77. Djomo, S.N.; Knudsen, M.T.; Martinsen, L.; Andersen, M.S.; Ambye-Jensen, M.; Møller, H.B.; Hermansen, J.E. Green proteins: An energy-efficient solution for increased self-sufficiency in protein in Europe. Biofuels Bioprod. Biorefining 2020, 14, 605-619. [CrossRef]

78. Chalamoński, M.; Szymczak, M. The dried sludge as alternative fuel. J. Civ. Eng. Environ. Archit. 2017, XXXIV, 35-42.

79. Szydełko, A.; Pawlak, M. Combustion and co-incineration of sewage sludge with mineral additives in terms of chlorine binding and chloride corrosion. Energetic Noteb. 2014, 1, 165-174.

80. Werle, S. Thermal methods of sewage sludge management. Energy from wastewater. Therm. Prof. Energy 2010, 9, $28-32$.

81. Czyżyk, F.; Kozdraś, M. Chemical properties and composting of sludge from a rural wastewater treatment plant. Water Environ. Rural Areas 2004, 4, 559-569.

82. Ministry of the Environment. The Strategy for Dealing with Municipal Sewage Sludge for the Period 2019-2022. 2018. Available online: https:/ / www.gov.pl/web/srodowisko/planowanie-gospodarki-odpadami (accessed on 8 March 2021).

83. Statistics Poland. Local Data Bank. 2021. Available online: https://bdl.stat.gov.pl/BDL/dane/teryt/jednostka (accessed on 8 March 2021).

84. Mayor of the City of Ostrołęka. Environmental Protection Program of the City of Ostrołeka for 2017-2020 with a Perspective until 2024. 2017. Available online: https:/ /bip.um.ostroleka.pl/artykul/117/4275/program-ochrony-srdoowiska-na-lata-2017-2020-zperspektywa-do-2024-roku (accessed on 8 March 2021). 
85. Mayor of the Goworowo Commune. Analysis of the State of Municipal Waste Management in the Commune. 2020. Available online: http:/ / goworowo.pl/gmina/gospodarka-odpadami (accessed on 9 March 2021).

86. The minister of Environment. The Ordinance on Landfill Limitation Levels for Biodegradable Municipal Waste Mass. 2017. Available online: http:/ / isap.sejm.gov.pl/isap.nsf/DocDetails.xsp?id=WDU20170002412 (accessed on 9 March 2021).

87. Cuong, T.T.; Le, H.A.; Khai, N.M.; Hung, P.A.; Linh, L.T.; Thanh, N.V.; Tri, N.D.; Huan, N.X. Renewable energy from biomass surplus resource: Potential of power generation from rice straw in Vietnam. Sci. Rep. 2021, 11, 792. [CrossRef]

88. Hansen, J.H.; Hamelin, L.; Taghizadeh-Toosi, A.; Olesen, J.E.; Wenzel, E. Agricultural residues bioenergy potential that sustain soil carbon depends on energy conversion pathways. GCB Bioenergy 2020, 12, 1002-1013. [CrossRef]

89. Statistics Poland. Statistical Yearbook of Agriculture. 2020. Available online: https://stat.gov.pl/obszary-tematyczne/rocznikistatystyczne/roczniki-statystyczne/rocznik-statystyczny-rolnictwa-2019,6,13.html (accessed on 24 March 2021).

90. Ministry of Climate and Environment. National Energy and Climate Plan for 2021-2030. 2019. Available online: https: / / www.gov.pl/web / klimat/krajowy-plan-na-rzecz-energii-i-klimatu (accessed on 4 December 2020).

91. Dyjakon, A. The influence of apple orchard management on energy performance and pruned biomass harvesting for energetic applications. Energies 2019, 12, 632. [CrossRef]

92. Dyjakon, A.; den Boer, J.; Gebresenbet, G.; Bosona, T.; Adamczyk, F. Economic analysis of the collection and transportation of pruned branches from orchards for energy productions. Wood Res. Pap. Rep. Announc. 2020, 63, 125-140.

93. Mayor of the Goworowo Commune. Study of the Conditions and Directions of Spatial Development. 2017. Available online: http:/ / bip.goworowo.pl/?k=247 (accessed on 22 January 2021).

94. Marshal's Office of the Mazowieckie Voivodeship. A Summary of the Data from the Land and Building Register of the Mazowieckie Voivodship. 2017. Available online: https:/ / gis.wrotamazowsza.pl/bezplatne-dane/ (accessed on 19 March 2021).

95. Marshal's Office of the Mazowieckie Voivodeship. A Summary of the Data from the Land and Building Register of the Mazowieckie Voivodship. 2018. Available online: https:/ / gis.wrotamazowsza.pl/bezplatne-dane/ (accessed on 19 March 2021).

96. Marshal's Office of the Mazowieckie Voivodeship. A summary of the Data from the Land and Building Register of the Mazowieckie Voivodship. 2020. Available online: https:/ /gis.wrotamazowsza.pl/bezplatne-dane/ (accessed on 19 March 2021).

97. Statistics Poland. Statistical Yearbook of Agriculture. 2019. Available online: https://stat.gov.pl/obszary-tematyczne/rocznikistatystyczne/roczniki-statystyczne/rocznik-statystyczny-rolnictwa-2018,6,12.html (accessed on 24 March 2021).

98. Dyjakon, A.; den Boer, J.; Szumny, A.; den Boer, E. Local energy use of biomass from apple orchards-An LCA study. Sustainability 2019, 11, 1604. [CrossRef]

99. Verkerk, P.J.; Fitzgerald, J.B.; Datta, P.; Dees, M.; Hengeveld, G.H.; Lindner, M.; Zudin, S. Spatial distribution of the potential forest biomass availability in Europe. For. Ecosyst. 2019, 6, 5. [CrossRef]

100. Holeksa, J.; Kapusta, P.; Budziakowska-Kubik, E.; Izworska, K.; Kurek, P.; Piechnik, Ł.; Szarek-Łukaszewska, G.; Wojterska, M.; Zielonka, T.; Żywiec, M. Stock of deadwood in the Niepołomice Forest as a result of long-term forest use and short-term protection within the Natura 2000 network. Fragm. Florist. Et Geobot. Pol. 2020, 27, 119-139.

101. Sierota, Z.; Grodzki, W.; Szczepkowski, A. Abiotic and biotic disturbances affecting forest health in Poland over the past 30 years: Impacts of climate and forest management. Forests 2019, 10, 75. [CrossRef]

102. Kaliszewski, A. Forest policy goals in Poland in light of the current forestry aims in Europe Part 3. European priorities for the forest policy in Polish programmes and strategies. For. Res. Pap. 2018, 79, 211-227. [CrossRef]

103. Van Meerbeek, V.; Ottoy, S.; De Meyer, A.; Van Schaeybroeck, T.; Van Orshoven, J.; Muys, B.; Hermy, M. The bioenergy potential of conservation areas and roadsides for biogas in an urbanized region. Appl. Energy 2015, 154, 742-751. [CrossRef]

104. Rocchi, L.; Paolotti, L.; Fagioli, F.F.; Boggia, A. Production of insulating panel from pruning remains: An economic and environmental analysis. Energy Procedia 2018, 147, 145-153. [CrossRef]

105. Bautista, S.; Camargo, M.; Bachmann, C. Sustainable roadside management from an innovative approach to ecosystem services and bioenergy generation. In Proceedings of the 2020 IEEE International Conference on Engineering, Technology and Innovation (ICE/ITMC), Cardiff, UK, 15-17 June 2020.

106. O'Sullivan, O.S.; Holt, A.R.; Warren, P.H.; Evans, K.L. Optimising UK urban road verge contributions to biodiversity and ecosystem services with cost-effective management. J. Environ. Manag. 2017, 191, 162-171. [CrossRef] [PubMed]

107. Meyer, A.K.P.; Ehimen, E.A.; Holm-Nielsen, J.B. Bioenergy production from roadside grass: A case study of the feasibility of using roadside grass for biogas production in Denmark. Resour. Conserv. Recycl. 2014, 93, 124-133. [CrossRef]

108. Mudryk, K.; Jewiarz, M.; Wróbel, M.; Niemiec, M.; Dyjakon, A. Evaluation of urban tree leaf biomass-potential, physicomechanical and chemical parameters of raw material and solid biofuel. Energies 2021, 14, 818. [CrossRef]

109. Ciria, C.S.; Sanz, M.; Carrasco, J.; Ciria, P. Identification of arable marginal lands under rainfed conditions for bioenergy purposes in Spain. Sustainability 2019, 11, 1833. [CrossRef]

110. Fernando, A.L.; Costa, J.; Barbosa, B.; Monti, A.; Rettenmaier, N. Environmental impact assessment of perennial crops cultivation on marginal soils in the Mediterranean Region. Biomass Bioenergy 2018, 11, 174-186. [CrossRef]

111. Pandey, V.C.; Bajpai, O.; Singh, N. Energy crops in sustainable phytoremediation. Renew. Sustain. Energy Rev. 2016, 54, 58-73. [CrossRef]

112. Dauber, J.; Miyake, S. To integrate or to segregate food crop and energy crop cultivation at the landscape scale? Perspectives on biodiversity conservation in agriculture in Europe. Energy Sustain. Soc. 2016, 6, 25. [CrossRef] 
113. Regional Director of Environmental Protection in Warsaw and Regional Director of Environmental Protection in Białystok. The Plan of Protection Tasks for the Natura 2000 PLB140014. 2016. Available online: http://crfop.gdos.gov.pl/CRFOP/widok/ viewnatura2000.jsf?fop=PL.ZIPOP.1393.N2K.PLB140014.B (accessed on 19 March 2021).

114. Regional Director of Environmental Protection in Warsaw. The Plan of Protection Tasks for the Natura 2000 PLB140007. 2016. Available online: http:/ / crfop.gdos.gov.pl/CRFOP/widok/viewnatura2000.jsf?fop=PL.ZIPOP.1393.N2K.PLB140007.B (accessed on 19 March 2021).

115. Golimowski, W.; Butlewski, K.; Gracz, W.; Marcinkowski, D.; Konieczny, R. Energy and environmental potential of grasslands in Poland. In Renewable Energy Sources: Engineering, Technology, Innovation, 1st ed.; Mundryk, K., Werle, K., Eds.; Springer: Cham, Switzerland, 2018; pp. 107-117.

116. Statistics Poland. Statistical Yearbook of Agriculture. 2021. Available online: https://stat.gov.pl/obszary-tematyczne/rocznikistatystyczne/roczniki-statystyczne/rocznik-statystyczny-rolnictwa-2020,6,14.html (accessed on 28 March 2021).

117. Duda, J.; Wasilewski, M. Innovative technology for disposal of sewage sludge. In Innovation in Management and Production Engineering, 1st ed.; Knosala, R., Ed.; Publishing House of the Polish Production Management Society: Opole, Poland, 2014; pp. 68-77.

118. Czop, M.; Jarzabkowska, N. Testing fuel properties of municipal sewage sludge. Arch. Waste Manag. Environ. Prot. 2016, 18, 51-62.

119. Listosz, A.; Kowalczyk-Juśko, A.; Mazur, A.; Jóźwiakowski, K.; Gizińska-Górna, M.; Pytka, A.; Marzec, M. The state and the perspectives of the ecoenergy infrastructure development in Biała Podlaska county p. i. state analysis. Water-Environ. Rural Areas 2017, 17, 81-93. 